\title{
Assessing Test Feedback Strategies Adopted By Primary School Teachers In Anambra State
}

Nneka Chinyere Ezeugo, Nwafor Orizu College of Education, Nigeria

\begin{abstract}
In learning new skills, it is necessary that students receive some information (feedback), that tells them if they are on the right track. The strategies, tactics or means through which teachers provide feedback to pupils after assessments are, however, a source of concern. Thus, this study aimed at assessing test feedback strategies/tactics adopted by primary school teachers in Anambra State, Nigeria. This study is a descriptive survey conducted in Anambra State, a south-eastern State in Nigeria. The sample of the study consisted of 500 teachers drawn from 1054 public primary schools in the state. The study tested two hypotheses and answered two research questions. The instrument used for collecting data is a researcher-developed questionnaire, titled "Test Feedback Strategy Assessment Questionnaire" (TFSAQ). Mean, standard deviation and t-test were adopted to analyze the data collected. The study revealed that teachers majorly gave feedbacks in writing or print form which included handwritten comments on students' assessed work, written numeric scores, grades, averages or positions, etc. They also gave face-to-face feedbacks to whole classes, individual students and small groups of students. Most of the teachers did not use electronic feedbacks. The feedbacks were of fairly good quality. The school location and the level of a class taught had no significant influence on teachers' responses. As a result of the findings, the researcher recommended among other things that teachers should be given more training especially on electronic feedback strategies as well as ways of improving the qualities of their test feedbacks.
\end{abstract}

Keywords: Assessment; Feedback; Feedback Strategy; Feedback Quality

\section{INTRODUCTION}

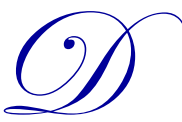

etermining the effectiveness of the teaching/learning process demands constant assessment of the level of attainment of the stated instructional objectives. Assessment according to Airasian (1996), "is the process of collecting, synthesizing and interpreting information to aid in decision making" (p.4). It includes all the different ways teachers gather information in their classroom. Similarly, Black and Dylan (1998) stated that it refers to "all those activities undertaken by teachers and by their students that provide information to be used as feedback to modify teaching and learning activities" (p.140). According to them, it is one of the most tasking aspects of teaching, nevertheless, assessing pupils effectively improves the instructional process and forms a vital part of effective classroom teaching. By implication, classroom assessment may remain irrelevant if it does not aid in improving instruction and overall student's achievement.

A test is one of the types of assessment information teachers deals with the classroom. It is a formal systematic procedure used in gathering information about pupils' behavior and achievement. Pupil behavior and achievementare categorized as one of the many strategies of assessment. It is observed that primary school teachers in Anambra State administer different kinds of assessments in the classroom like paper and pencil tests, projects, take-home assignments, etc. These assessment strategies are done on regular basis as demanded by the Basic Education Curriculum. The purpose of these different forms of assessment is to serve as a means of guiding, directing and monitoring learning progress and diagnosing learning problems (Airasian, 1996; Department of Education and Training, 2013). According to Hosp, Hosp, and Howell, (2007:11) "assessment should be efficient and provide information that will guide instruction and improve student outcomes." They further stated concerningCurriculum-Based Measurement (CBM), that assessment data helps us to decide which student needs 
help and which don't; when to move on to new goals or modify instruction; what kind of assistant a student needs and the overall effectiveness of efforts across all students. However, Department of Education and Training (2013), stated that for improved performance, the assessment must involve feedback and reflection. Assessment methods should give students the opportunity to receive feedback from their performance and also reflect on their overall learning. By so doing, assessment serves as a developmental activity.

\section{LITERATURE REVIEW}

Research evidence abounds, which point to the fact that feedback is essential and indispensable to student's learning (Race, 2001; Hatziapostolou \& Paraskakis, 2010).

Feedback is defined by Wilbert, Grosche, and Gerdes (2010), "as the information provided to a student as a result of the outcome of an action" (p.43). According to Wiggins (2012), "feedback is the information about how we are doing in our efforts to reach a goal" (p.10). It is normally something which happens as a result of some learning oriented action and may be provided after the action, during the action or both and sometimes even in the absence of any learning action (Race, 2001). In agreement with this assertion, Evans (2013) stated that assessment feedback refers to "all feedback exchanges generated within assessment design, occurring within and beyond the immediate learning context, being overt or covert, (actively and/or passively sought and/or received) and importantly drawing from a range of sources"(p.70). Such sources of feedback include fellow learners, tutors, trainers, instructors, expert witnesses and even the learner himself (Race, 2001). However, the present study focuses on feedback information generated by the teachers. Efforts have been made by researchers to categorize feedback in many ways and for several reasons. They include Intentional feedback/Negative feedback, written feedback/oral feedback, direct feedback/indirect or meditated feedback, descriptive feedback, and evaluative feedback. (Race 2001; Lipnevich \& Smith, 2008; Wilbert et al, 2010).

Bangert-Drowns, Kulik, and Morgan (1991), equally outlined different types of feedback. They include correction of errors, presenting prototype response for the students, displaying for the students the aftermath of their response as well as explaining the suitability of an answer. Equally, Hattie and Timperley (2007), outlined four levels of feedback which are, "the task level, process level, self-regulation and the self-level" (p.87). According to them, process and self-regulation levels best suited for facilitating the individuals' improvement. Rheinberg (1980) and Wilbert et al. (2010), further distinguished between three evaluative feedbacks as a result of the norm of reference adopted in evaluating students' achievement. The social evaluative feedback is given when the achievement of the individual learner evaluated by comparing them with the achievement of others. Individual evaluative feedback focuses on the students' learning progress or achievement from his or her earlier performances. Criteria feedback occurs when properties inherent in different tasks are used as the basis of comparison.

Different strategies are adopted by teachers in given test feedbacks to students. The term test feedback according to Hatziapostolou and Paraskakis (2010), involves two components which are "the contents of the feedback itself and the method(s) used to communicate the feedback to the students" (p. 111). The strategy is vital because the procedure used may either attract or discourage the students from paying attention to the entire process. In discussing formative feedback, Hatziapostolou and Paraskakis (2010), pointed out that it can be communicated in different ways which include traditional methods like writing comments on the work of a student, giving them feedback as word processed print-outs and electronic feedback methods like sending emailed comments to students and other sophisticated procedures that enable teachers to add their clarifications and comments to works submitted electronically. The result agrees with the suggestion of UQ Assessment Briefs (2009), who stated that some of the strategies or tactics that could be adopted in giving feedbacks are:

A. Feedback in writing or print

i. Handwritten comments on (or about) students' assessed work.

ii. Word-processed overall comments on each students' assessed work.

iii. Model answers or solutions, issued to students along with their marked.

iv. Assignment return sheets.

v. Word-processed overall class reports on an assignment.

vi. Codes are written on students' work, debriefed in a whole-group session. 

B. Face-to-face feedback
i. face-to-face feedback to whole classes.
ii. face-to-face feedback to individual students.
iii. face-to-face feedback to a small group of students.
C. Electronic feedback
i. E-mailed comments on students' assessed work.
ii. Using computer conferences for overall comments on batches of students' work.
iii. Computer-delivered feedback" (P.1-2).

This study, therefore, seeks to assess the feedback strategies adopted by teachers in the Anambra state of Nigeria.

Feedback in writing or print which refers to a process of writing directly on students' work or supplying such comments in printed form alongside the work (Race, 2001), can be a powerful tool for helping the pupils to move forward in their learning. It enables the pupils to refer to the feedback over and over again. In feedbacks given to students orally, they may sometimes forget what was said. On the other hand, Nash et al, (n.d.), developed and studied the impact of a strategy which they referred to as first feedback face-to-face (FFF) strategy. The result according to them "is a two-way feedback strategy that aims to support a collaborative dialogue on feedback between student and tutors, based on the principles of constructivist learning" (p.2). The technologies used in electronic feedback gives the students opportunities to receive corrections outside the routine school hours as well as teacher's ability to reach out to many students at the same time. It thus enables the students to develop more concentration on their learning (Gikandi, Morrow, \& Davis, 2011).

Moreover, Stenger, (2014), observed that feedbacks are not equally useful and in fact can be counterproductive especially if presented in a solely negative or corrective way. She thus outlined some research-based tips for quality feedback to include:

1. Be as specific as possible

2. The sooner, the better

3. Address the learner's advancement towards a goal

4. Giving feedback carefully

5. Incorporating learners in the feedback process (p.1)

In their own opinion, The Department of Education and Training (2013) said that proper result feedbacks:
a. Develops self-assessment skills
b. Encourages dialogue
c. Clarifies what good performance is
d. Is timely
e. Guides learning
f. Stimulates self-belief or positive motivational belief

Equally, Race, (2001) is of the opinion that good feedback should be timely, empowering, manageable, fit individual student's achievement, nature and personality as well as open doors and not close them by ensuring that words with "final language" implications like poor or excellent are avoided. The implication demands that teachers' feedback strategies should be assessed to ensure that they meet up with the desired quality. Thus, the problem of this study is to assess teachers' feedback practices with the aim of determining the type of feedbacks strategies adopted and the overall qualities of the result feedbacks.

\section{Purpose of The Study}

This study aimed at assessing the type of test feedback strategies or tactics adopted by primary school teachers in Anambra State. Specifically, it aimed at finding out.

1. The methods or tactics utilized by primary school teachers in giving test feedbacks. 
2. The quality of the test feedbacks giving by primary school teachers in Anambra State.

\section{Research Questions}

1. What are the strategies/tactics utilized by primary school teachers in giving test feedbacks?

2. What are the qualities of test feedbacks given by primary school teachers in Anambra State?

\section{Null Hypothesis}

1. The mean score of teachers at the urban and rural areas on the test feedback strategies they adopt in primary schools is not statistically different.

2. The mean score of teachers at junior and senior primary school levels on the test feedback strategies they utilize is not significantly different.

\section{RESEARCH METHODOLOGY}

A survey research design was adopted in this study to look into test feedback strategies or tactics adopted by primary school teachers in Anambra State, Nigeria.

The study population was made up of 9884 primary school teachers in public schools in the 21 Local Government Areas of Anambra State (Government of Anambra State, Statistical Year Book, 2013). The sample consisted of 500 teachers drawn through a multi-stage sampling technique. Anambra is a state consisting of six education zones. First, simple random sampling was used to select four education zones out of the six education zones, and two local government areas from each of the sampled education zones. Three primary schools were drawn from each local government area using simple random sampling technique. Then all the teachers in the sampled schools that were willing to respond to the questionnaire were used.

A researcher-developedLikert-type questionnaire, titled 'Test Feedback Strategy Assessment Questionnaire (FAQ) used for data collection. The questionnaire consisted of sections A, B, and C. Section A sought personal information of the respondents, section $\mathrm{B}$ focused on the type of test feedback strategies/tactics adopted by teachers while section $\mathrm{C}$ elicited information on the quality of the test feedbacks strategies.

The instrument was validated by two experts, one in measurement and evaluation and the other in educational psychology from Nwafor Orizu College of Education, Nsugbe. The reliability was established using the test-re-test reliability method, and a correlation coefficient of 0.89 was derived. The distribution and collection of the questionnaires was done by the researcher and five trained research assistants. The research assistants were instructed to ensure prompt collection of the instruments. The prompt collection helped to increase the rate of returns, although $100 \%$ return was not achieved.

\section{Method of Data Analysis}

The information gathered from the questionnaire were first coded into the Statistical Package for Social Science (SPSS) computer software. The research questions are answered by computing the mean and standard deviations; the hypotheses are tested at 0.05 level of significance by calculating the t-test statistic. 


\section{RESULTS}

Research Question 1: What are the strategies/tactics utilized by primary school teachers in giving test feedbacks?

Table 1. Mean and standard deviation of the teachers' responses on the strategies/tactics they adopt in giving test feedback to pupils.

\begin{tabular}{c|l|r|r}
\hline S/N & \multicolumn{1}{c}{ Items } & \multicolumn{2}{c}{ X } \\
\hline Feedback in writing or print & 3.34 & .79 \\
\hline 1 & Hand-written comments on (or about) pupils assessed work & 3.04 & .95 \\
\hline 2 & Overall the comments on each pupil's assessed work in the word-processed form. & 2.94 & 1.03 \\
\hline 3 & Model answers given to pupils along with their marked work. & 3.15 & .957 \\
\hline 4 & Use of assignment return sheets. & 2.88 & 1.07 \\
\hline 5 & Giving overall class reports on an assignment in word-processed form. & 2.60 & 1.09 \\
\hline 6 & Written codes on pupils assessed works with explanations given in an entire class session. & 2.89 & 1.11 \\
\hline 7 & Written numeric scores, percentage score, grades, positions on students work & 3.34 & .91 \\
\hline 8 & Written comments like excellent, good, fair and poor. & 3.34 & .89 \\
\hline Face-to-face oral feedback & Giving feedback orally to the whole class & 3.20 & .84 \\
\hline 9 & Gace facing oral feedback to individual students. & 2.99 & 1.00 \\
\hline 10 & Face & & \\
\hline 11 & Face facing oral feedback to small groups of students. & 1.36 & .547 \\
\hline Electronic Feedback & E-mailed comments on students assessed work. & 1.28 & .50 \\
\hline 12 & Giving overall comments on batches of pupils work using computer conferences. & 1.31 & .54 \\
\hline 13 & Computer-delivered feedback & & \\
\hline
\end{tabular}

Table 1 above shows that the teachers accepted all the items as strategies they adopt in giving feedbacks to pupils except for 13, 14 and 15 on electronic feedbacks. The result is because they had mean values below 2.50 which is the benchmark for acceptance.

Research Question 2: What are the qualities of test feedbacks given by primary school teachers in Anambra State?

Table 2. Mean and standard deviation on responses of the teachers on the qualities of their test feedbacks.

\begin{tabular}{c|l|r|r}
\hline S/N & \multicolumn{1}{|c|}{ Items } & X & 2.68 \\
\hline 1 & Are clear, specific and concise & 2.25 & 1.25 \\
\hline 2 & Are given while all the details are fresh in the pupil's mind. & 2.32 & .86 \\
\hline 3 & Are tied to specific goals. & 3.20 & .91 \\
\hline 4 & Involve learners in the process. & 3.46 & .98 \\
\hline 5 & Are presented with the right language. & 3.50 \\
\hline 6 & Act as a guide to learning. & 2.32 & .74 \\
\hline 7 & Comes in real time to reshape performance. & 3.21 & .84 \\
\hline 8 & Comes at the end of the activity & 2.10 & .91 \\
\hline 9 & Encourages effective dialogue with students. & 3.31 \\
\hline 10 & Clarifies what good performance is. & 3.38 & 2.05 \\
\hline 11 & Develops pupils' self-assessment skills. & 2.03 & .82 \\
\hline 12 & Involves the use of highly descriptive rubrics & .82 \\
\hline
\end{tabular}

In table 2 above, the teachers accepted 8 out of the 12 items, while items 2, 7,9 and 12 were rejected because they had mean scores below 2.50 .

Null Hypothesis 1: The mean score of teachers in the urban and rural areas, based on the test feedback strategies they adopt in primary schools, is not statistically different. 
Table 3. T-test on the mean score of primary school teachers in the urban and rural areas on test feedback strategies

\begin{tabular}{l|c|c|c|c}
\hline \multicolumn{1}{c|}{ Location } & $\mathbf{N}$ & Mean & Standard Deviation & Standard Error Mean \\
\hline Urban & 268 & 2.98 & .24 & .01 \\
\hline Rural & 232 & 2.97 & .27 & .02 \\
\hline
\end{tabular}

\begin{tabular}{|c|c|c|c|c|c|c|c|c|c|}
\hline \multicolumn{10}{|c|}{ Independent Sample Test } \\
\hline \multirow[b]{2}{*}{ Mean } & \multicolumn{2}{|c|}{$\begin{array}{l}\text { Levene's Test for } \\
\text { equality of variance }\end{array}$} & \multirow[b]{2}{*}{$\mathbf{t}$} & \multirow[b]{2}{*}{ df } & \multirow[b]{2}{*}{$\begin{array}{c}\text { Sig } \\
\text { (z-tailed) }\end{array}$} & \multirow[b]{2}{*}{$\begin{array}{c}\text { Mean } \\
\text { diff }\end{array}$} & \multirow[b]{2}{*}{$\begin{array}{l}\text { Std error } \\
\text { diff }\end{array}$} & \multicolumn{2}{|c|}{$\begin{array}{l}95 \% \text { confidence interval } \\
\text { of the difference }\end{array}$} \\
\hline & $\mathbf{F}$ & Sig & & & & & & Lower & upper \\
\hline $\begin{array}{l}\text { Equal variance } \\
\text { assumed }\end{array}$ & 0.49 & .826 & .339 & 498 & .734 & .00770 & .02269 & -.03687 & .05227 \\
\hline $\begin{array}{l}\text { Equal variance } \\
\text { not assumed }\end{array}$ & & & .337 & 469.881 & .736 & .00770 & .02285 & -.03720 & .05260 \\
\hline
\end{tabular}

The SPSS result presented in table 3 reveals that the calculated t-value has a probability level 0.734 or 0.736 which is above the 0.05 significant level. As such the null hypothesis that no significant difference exists in the mean responses of primary school teachers from urban and rural areas on feedback strategies adopted are accepted.

Null Hypothesis 2: The mean score of primary school teachers at the junior and senior primary levels on the text feedback strategies they adopt is not significantly different.

Table 4. $t$-test on the mean score of junior and senior primary school teachers on test feedback strategies adopted.

\begin{tabular}{l|l|c|c|c}
\hline \multicolumn{1}{c|}{ Class type } & NA & Mean & Standard Deviation & Standard Error Mean \\
\hline Senior & 256 & 2.9684 & .24939 & .01559 \\
\hline Junior & 244 & 2.9771 & .25665 & .01643 \\
\hline
\end{tabular}

\begin{tabular}{|c|c|c|c|c|c|c|c|c|c|}
\hline \multirow[b]{3}{*}{ Mean } & \multicolumn{7}{|c|}{ Independent Sample Test } & \multirow{2}{*}{\multicolumn{2}{|c|}{$\begin{array}{l}95 \% \text { confidence interval } \\
\text { of the difference }\end{array}$}} \\
\hline & $\begin{array}{r}\text { Leven } \\
\text { equality }\end{array}$ & $\begin{array}{l}\text { st for } \\
\text { riance }\end{array}$ & & & & & & & \\
\hline & $\mathbf{F}$ & Sig & $\mathbf{t}$ & df & $\begin{array}{c}\text { Sig } \\
\text { (z-tailed) }\end{array}$ & $\begin{array}{l}\text { Mean } \\
\text { diff. }\end{array}$ & $\begin{array}{l}\text { Std error } \\
\text { diff. }\end{array}$ & Lower & upper \\
\hline $\begin{array}{l}\text { Equal variance } \\
\text { assumed }\end{array}$ & 1.726 & .190 & -.396 & 498 & .700 & $\begin{array}{c}- \\
.00874\end{array}$ & .02263 & -.05320 & .03573 \\
\hline $\begin{array}{l}\text { Equal variance } \\
\text { not assumed }\end{array}$ & & & -.386 & 485.082 & .700 & $\begin{array}{c}- \\
.00874\end{array}$ & .02265 & -.05324 & .03576 \\
\hline
\end{tabular}

The result of the SPPS analysis presented above reveals that the calculated t-value has a probability level 0.700 , which is above the 0.05 significant level. Thus, the null hypothesis is accepted, which means that no significant difference exists in the mean responses of teachers at the junior and senior primary levels on test feedback strategies adopted.

\section{DISCUSSION OF FINDINGS}

The responses to research question one showed that the test feedback strategies mostly adopted by primary school teachers were written feedbacks or feedbacks in printed form as well as face to face oral feedbacks to entire class, individual and small group of students. Majority of the teachers did not utilize electronic feedbacks. To add weight to this finding, the test of hypothesis one and two showed that there is no significant difference in the mean ratings of teachers in different school locations and class levels on the feedback strategies they adopted.

This finding agrees with Hyland (2015) who stated that providing students with written feedback is a common practice in education. It is the strategy mostly utilized in the academic setting (Mathisen, 2012). Hyland further elaborated that diligent teachers also provided students with detailed written correction feedback of their errors in 
addition to their scores. The effort is aimed at improving learning. Writing in support of this assertion, William (2014), pointed out that grades, ranking, and teachers written comments on students' tests constituted the most common and oldest forms of feedback in schools. Although having teachers write corrective comments on pupils assignment is seen as the focal point of the feedback process (Nicol, 2010), there is a lot ofmisgiving with 'written comments only' type of feedbacks by teachers and students as seen from some researchers. Nicol, (2010) therefore, went on to propose that result feedback to students should be seen as a process of dialogue which encompasses twoway interactions existing between the teachers and students, students and their peers and also active learner participation in the learning process. Equally, Tom, Morni, Metom, and Joe (2013) observed: "that teachers should complement written feedback with teacher-student conferences or other forms of feedback that will help low proficiency students make appropriate development in writing" (p. 79). Using written feedback together with teacher dialogue can sensitize students to derive meaning out of assessment feedbacks, and this enhances learning. Thus, Boud and Molloy (2012), observed that for feedback to foster learning, it should be repositioned:

1. "From an act of the teachers to an act of the students in which teachers are part(from unilateral to coconstructed; from monologue to dialogue)

2. From the almost exclusive use of teachers to that of many others (from a single source to multiple sources).

3. From an act of students as individuals to one that necessarily implicates peers (from individualistic to collectivist).

4. From a collection of isolated acts to a designed sequence of development over time (from unitary items to curriculum)" (p. 710).

The resultsemphasize the need to broaden feedback strategies to include face-to-face feedback practices. Thus, the finding of this study which revealed a combination of both written and face-to-face feedback among primary school teachers is a welcome development towards improving students learning.

Tables 1, however, revealed that majority of the teachers were not utilizing electronic feedback strategies either as emailed comments, computer conferences or computer-delivered feedback. This finding is not encouraging given the importance of electronic feedback strategies especially its ability to give the students opportunities to receive corrections outside the routine school hours (Gikandiet et al., 2011). Equally, Huett (2004), pointed out that the use of e-mail "correspondence in the educational environment provides many relative advantages such as, speed of delivery, improved and more immediate communication, freedom from the constraints of location and time, potential for increased interaction, development of writing skills, decreased social isolation, increased internet experience, extended learning opportunities to name a few" (Discussion of Philosophical Perspective, para. 1). Also reporting a study carried out by Leh in 2001 who investigated "the appropriateness of computer-mediated communication (CMC) in distance learning, Huett (2004), stated that Leh found CMC as beneficial for communication and learning", (Feedback through Email, para. 5). Teachers' lack of usage of this strategy is attributed to several factors which include: inexperience, lack of technical expertise, lack of adequate training and availability of the facility, the problem of electrical power supply, time constraints and workload, etc.

In research question two, table 2 revealed that the teacher's feedbacks were clear, specific, concise, tied to definite goals, presented with the right language, guides learning, clarify what good performance is, and develops pupils self-assessment skills. These items agree with most of the attributes of quality feedback practice as outlined by Stenger, (2014); Race (2001) and the Department of Education and Training (2013). However, it is observed that the teachers' feedbacks were not ongoing, timely enough, did not involve the use of highly descriptive rubrics and although it incorporated the learners, the dialogic process was not very adequate. These point to the fact that teachers feedback practices were more summative than formative, lacked consistency and were conceptualized as a transmission process from teachers to the pupils. The resultis supported by the view of Nicol \& Macfarlane-Dick (2007) who observed that the feedback was dominated by the teachers and equally misconceived as their sole responsibility. They thus identified four problems associated with this transmission view as it relates to high education which are:

1. It discourages pupils empowerment and development of some skills necessary for lifelong learning.

2. The feedback message may be complicated and hard to decipher to help students regulate performance. 
3. It neglects the interaction of motivation and belief with the feedback given.

4. It gives the teacher a lot of burden regardingworkload.

These problems are even more critical with primary school pupils and teachers which is the focus of the present study. Rowe (n.d.) equally stated that since feedback is designed to enhance students learning, it is better to engage them in a two-way dialogue instead of providing feedback only at the end of the course. Students are given an ongoing formal and informal corrections feedback along with support on how to use the feedback information. This action will make teachers feedback practice more formative for quality children's learning.

\section{RECOMMENDATIONS}

Based on the findings the following recommendations are made:

1. Seminars, workshops, andtraining should be conducted for teachers to sensitize them on different feedback strategies for children's learning, and ways of improving feedback quality.

2. Primary school teachers should be made to undergo serious computer training to enhance their skills in computer usage.

3. Experts should teach computer appreciation as a primary school subject in the field which will ensure that the children be exposed to practical sessions.

4. The government should provide computers for the public primary schools in the state.

5. There should be a closer monitoring system by the school management to ensure that feedback practice is an ongoing process and the teachers maintain that consistency.

\section{SUGGESTIONS FOR FURTHER RESEARCH}

1. This study should be carried out with particular focus in different subject areas at the primary level.

2. Research on the problems encountered by teachers in administering test feedbacks at the primary levels should also be carried out.

\section{CONCLUSION}

Based on the preceding, it can be concluded that primary school teachers in Anambra State majorly adopted handwritten feedbacks/feedbacks in print as well as face-to-face feedback. They were deficient in the usage electronic feedback strategies. Also, teachers' feedback had some quality. However, it tended to be more feedback and lacked sufficient dialogue with the pupils. All these have implications for quality learning at the primary school level.

\section{AUTHOR BIOGRAPHY}

Ezeugo Nneka Chinyere is from Nkwelle, Uke in Idemili North L.G.A of Anambra State, South East of Nigeria. She obtained her Bachelors and Masters degrees in mathematics education from University of Ibadan and University of Nigeria Nsukka respectively. She subsequently obtained her Doctorate in Measurement and Evaluation from Nnamdi Azikiwe University Awka. Presently, she is a Chief Lecturer in the Department of Primary Education, Nwafor Orizu College of Education, Nsugbe, Anambra State. Assessing Test Feedback Strategies Adopted by Primary School Teachers in Anambra State. 


\section{REFERENCES}

Airasian, P.W. (1996). Assessment in the classroom. New York: McGraw Hill Inc.

Bangert-Drowns, R.L., Kulik, J.A., \& Morgan, M.T. (1991). The instructional effect of feedback in test-like events. Review of Educational Research, 61, 213-238

Black, P. \& Dylan, W. (1998). Inside the black box: Raising standard through classroom assessment. www.rdc.udel.edu/wpcontent/uploads/2015/04/InsideBlackBox.pdf

Boud, D. \& Molloy E. (2012). Rethinking models of feedback for learning: The Challenge of design. Assessment and Evaluation in Higher Education, 38(6),698-712.http://dx.doi.org/10.1080/02602938.2012.691462

Department of Education and Training (2013). Assessment advice. Last retrieved on21/7/2016 from www.education.vic.gov.au/.../teachers/

Evans, C. (2013). Making sense of assessment feedback in higher education. Review of Educational Research,83(1), 70-120.

Gikandi, J. W., Morrow, D. \& Davis, N. E.(2011). Online formative assessment in Higher education: A review of the literature. Science Direct,57(4), 2333-2351. Doi:10.1016/j.compedu.2011.06.004

Hattie, J. \& Timperley, H. (2007). The power of feedback. Review of Educational Research, 77(81). Retrieved on 20/7/2016 fromhttp://rer.sagepub.com/content/77/1/81

Hatziapostolou, T. \& Paraskakis, I. (2010). Enhancing the impact of formative feedback on student learning through an online feedback system. Electronic Journal of E-Learning, 8(2), 111-122. Files.eric.ed.gov/fulltext/EJ895699.pdf

Hosp, M. K., Hosp, J. L., \& Howell, K. W. (2007). The ABCs of CBM: A practical guide to curriculum-based measurement. London the Guilford press.

Huett, J. (2004). E-mail as an educational feedback tool: Relative advantages and implementation guidelines. Last retrieved on 24/9/2016 from itoll.org/journal/jun_04/article06.htm

Hyland, R., (2015).An investigation of how written feedback influences applied level mathematics students' perceptions of assessment. Electronic thesis and dissertations. The University of Windsor. Ontario Canada.

Lipnevich, A. A.\& Smith, J. K. (2008). Response to assessment feedback: The effects of grades, praise, and source of information. Educational Testing Service. Retrieved on 27/7/2016 from www.ets.org/media/Research/pdf/RR-0830.pdf

Making Sense of Assessment Feedback in Higher Education (2013). Review of Educational Research, 83(1), 70-120 Rer.sagepub.com/content/83/1/70.full

Mathisen, P. (2012). Video feedback in higher education - A contribution to improving the quality of written feedback. Nordic Journal of Digital Literacy.

Nash, G., Liebergreen, M., Turley, J., Grimmins, G., Bond, R., Oprescu, F., \& Dunn, P. (n.d.). The impact of first feedback faceto-face (FFF) on first-year students' meanings, perceptions and attitudes towards assessment feedback. Faculty of Arts and Business. The University of the Sunshine Coast.

Nicol, D. J. (2010). From monologue to dialogue: Improving written feedback processes in mass higher education. Assessment \& Evaluation in High Education,35(5) 501-517.

Nicol, D. J. \& Macfarlane-Dick, D. (2007). Formative assessment and self-regulated Learning: a model and seven principles of good feedback practice. Studies in Higher Education, 31(2). Last retrieved on 24/9/2016 from http://dx.doi.org/10.1080/0307507060052090.

Race, P. (2001). Using feedback to help the student to learn. The Higher Education Academy. Retrieve on 20/7/2016 fromwap.rdg.ac.uk/web/FILES/EngageinFeedback/Race-using-feedback-to-help-students-learn.pdf

Rheinberg, F. (1980). Leistungsbewertung and Lernmotivation (Appraisal of achievement and learning motivation). Gattingen: Hogrefe.

Rowe, R. (n.d.) Formative feedback: Feedback for learning. Toolkit for Learning and Teaching. The University of Sheffield. Last retrieved on 25/9/16 from https://www.sheffield.ac.uk/.../feedback/...

Stenger, M., (2014). 5 research-based tips for prodding students with meaningful feedback. Edutopia. Retrieved on 19/7/2016 from www.edutopia.org/.../tips-providing-...

Tom, A. A., Morni, A., Metom, L., \& Joe, S. (2013), Students' perception and preferences of written feedback in academic writing. Mediterranean Journal of Social Sciences, 4(11). Rome MCSER publishing.www.mcser.org/journal/index.../1300

UQ Assessment Briefs (2009). AUQ Assessment brief on “Using feedback to help students to learn”. (Brief No: 2 October 2009) http://www.uq.edu.au/tediteach/assessment/resources.html\#

Wiggins, G. (2012). Seven keys to effective Feedback. Educational Leadership, 70(1),10-16. Retrieved 20/7/2016 from http://www.ascd.org/publications/educational-leadership/sept12/vol70/numoi/seven-keys-to-Effective-feedback.aspx

Wilbert, J., Grosche, M. \& Gerdes, H. (2010). Effects of evaluative feedback learning disabilities. A Contemporary Journal,8(2), 43-45. Retrieve on 20/7/2016 fromwww.idworldwide.org/pdf/LDCJ/2010/09-10-Wilbert-Grosche-Gerder.pdf

William, D. (2014).Is the feedback you're giving students helping or hindering? Learning Sciences. Last retrieved on 23/9/2016 from http://www.dylanwiliamcenter.com/is-the-feedback-you-are-giving-students-helping-or-hindering/ 
